\title{
KEMAJUAN TEKNOLOGI DAN POLA HIDUP MANUSIA DALAM PERSPEKTIF SOSIAL BUDAYA
}

\author{
Muhamad Ngafifi \\ SMP Negeri 2 Sukoharjo Wonosobo
}

\begin{abstract}
Abstrak
Makalah ini bertujuan untuk: (1) mengetahui proses perkembangan kemajuan teknologi, (2) mengetahui perubahan pola hidup manusia akibat kemajuan teknologi, (3) mengetahui pengaruh kemajuan teknologi di bidang sosial budaya, dan (4) mendapatkan solusi dalam mengatasi dampak negatif dari kemajuan teknologi. Makalah ini merupakan hasil studi pustaka yang bersumber pada buku, artikel, jurnal, dan dilengkapi dengan hasil survei tentang penggunaan teknologi modern yang digunakan sebagai teknik pengumpulan datanya. Data yang diperoleh dianalisis deskriptif secara kritis oleh penulis dengan menggunakan pendekatan teori perubahan sosial budaya. Hasil pembahasan dalam makalah ini menunjukkan sebagai berikut: (1) kemajuan teknologi terus berkembang sangat pesat dan melahirkan masyarakat digital; (2) terjadi perubahan pola hidup manusia akibat kemajuan teknologi sehingga menjadi lebih pragmatis, hedonis, sekuler, dan melahirkan generasi instan namun juga mengedepankan efektifitas dan efisiensi dalam tingkah laku dan tindakannya; (3) kemajuan teknologi berwajah ganda karena menimbulkan pengaruh positif dan negatif bagi kehidupan manusia; (4) upaya untuk menekan dan mengatasi dampak negatif dari kemajuan teknologi dapat dilakukan dengan mensinergiskan peran keluarga, pendidikan, masyarakat, dan negara.
\end{abstract}

Kata kunci: teknologi, pola hidup, dan perubahan sosial budaya

\section{ADVANCES IN TECHNOLOGY AND PATTERNS OF HUMAN LIFE IN SOCIO-CULTURAL PERSPECTIVE}

\author{
Muhamad Ngafifi \\ SMP Negeri 2 Sukoharjo Wonosobo
}

\begin{abstract}
This paper aims to: 1) describe the process of technological advances, 2) identify the changes in the patterns of human life due to advances in technology, 3) determine the effect of technological advances in the field of socio-culture, and 4) provide a solution to overcome the negative impact of technological advances. This paper is a literature review of which the sources are books, articles, journals, and the results of a survey on the use of modern technology that is used as a data collection technique. Data were analyzed descriptively using the theory of socio-cultural change. The results are as follows: (1) technology advances continue to grow very rapidly and gave birth to the digital society; (2) there were changes in the patterns of human life due to advances in technology, that is people become more pragmatic, hedonistic, and secular, which is leading to an instant generation but they also promote effectiveness and efficiency in the behavior and actions; (3) dvances in technology cause positive and negative impact on human life; and (4) efforts to reduce and overcome the negative impacts of technological advances can be made by synergizing the role of family, education, community, and country.
\end{abstract}

Keywords: technology, patterns of human life, culture and social change 


\section{PENDAHULUAN}

Manusia menggunakan teknologi karena memiliki akal. Dengan akalnya manusia ingin keluar dari masalah, ingin hidup lebih baik, lebih aman, dan sebagainya. Perkembangan teknologi terjadi karena seseorang menggunakan akalnya untuk menyelesaikan setiap masalah yang dihadapinya.

Kemajuan teknologi adalah sesuatu yang tidak bisa dihindari dalam kehidupan ini, karena kemajuan teknologi akan berjalan sesuai dengan kemajuan ilmu pengetahuan. Setiap inovasi diciptakan untuk memberikan manfaat positif bagi kehidupan manusia. Teknologi juga memberikan banyak kemudahan, serta sebagai cara baru dalam melakukan aktivitas manusia. Manusia juga sudah menikmati banyak manfaat yang dibawa oleh inovasi-inovasi teknologi yang telah dihasilkan dalam dekade terakhir ini.

Pada era globalisasi saat ini, penguasaan teknologi menjadi prestise dan indikator kemajuan suatu negara. Negara dikatakan maju jika memiliki tingkat penguasaan teknologi tinggi (high technology), sedangkan negara-negara yang tidak bisa beradaptasi dengan kemajuan teknologi sering disebut sebagai negara gagal (failed country). Berikut ini 10 negara di dunia terhebat dengan penguasaan teknologi tinggi:

Tabel 1. 10 Negara Terhebat di Dunia Tahun 2012

\begin{tabular}{cl}
\hline NO & \multicolumn{1}{c}{ NAMA NEGARA } \\
\hline 1 & Finlandia \\
2 & Amerika Serikat \\
3 & Jepang \\
4 & Swedia \\
5 & Korea Utara \\
6 & Belanda \\
7 & Inggris \\
8 & Singapura \\
9 & Korea Utara \\
10 & Australia \\
\hline
\end{tabular}

Sumber:(http://top10newsworld.blogspot.com/ 2012/11/10)

Negara-negara yang berjaya ini menjadi adikuasa (powerful), kaya raya (prosperous), dan berprestise (prestigious) karena bermodalkan teknologi. Oleh karena itu, memasuki Milenium III ini, tidak mengherankan berkembang keinginan untuk memanfaatkan, mengembangkan, dan menguasai teknologi.
Terobosan teknologi di bidang mikro-elektronika, bio teknologi, telekomunikasi, komputer, internet, dan robotik telah mengubah secara mendasar cara-cara kita mengembangkan dan mentransformasikan teknologi ke dalam sektor produksi yang menghasilkan barang dan jasa dengan teknologi tinggi (Buhal, 2000, p.i).

Pada satu sisi, perkembangan dunia IPTEK yang demikian mengagumkan itu memang telah membawa manfaat yang luar biasa bagi kemajuan peradaban umat manusia. Jenis-jenis pekerjaan yang sebelumnya menuntut kemampuan fisik yang cukup besar, kini relatif sudah bisa digantikan oleh perangkat mesin-mesin otomatis. Demikian juga ditemukannya formulasi-formulasi baru kapasitas komputer, seolah sudah mampu menggeser posisi kemampuan otak manusia dalam berbagai bidang ilmu dan aktivitas manusia. Ringkas kata kemajuan teknologi saat ini benar-benar telah diakui dan dirasakan memberikan banyak kemudahan dan kenyamanan bagi kehidupan umat manusia (Dwiningrum, 2012, p.171).

Di sisi lain, manusia tidak bisa menipu diri sendiri akan kenyataan bahwa teknologi mendatangkan malapetaka dan kesengsaraan bagi manusia modern. Kemajuan teknologi, yang semula untuk memudahkan manusia, ketika urusan itu semakin mudah, maka muncul "kesepian" dan keterasingan baru, yakni lunturnya rasa solidaritas, kebersamaan, dan silaturrahmi. Contohnya penemuan televisi, komputer, internet, dan handphone telah mengakibatkan kita terlena dengan dunia layar. Layar kemudian menjadi teman setia, bahkan kita lebih memperhatikan dunia layar dibandingkan istri/suami, dan anak sekalipun. Hampir setiap bangun tidur kita menekan tombol televisi untuk melihat layar, pergi ke kantor tekan tombol handphone melihat layar untuk ber-sms, BBM (Blackberry Messenger) ria atau main game, sampai di kantor sudah tersedia layar komputer atau layar televisi. Begitu juga ketika pulang dari kantor sampai rumah, layar televisi yang dilihat terlebih dahulu bukan istri dan anak. SMS dan BBM membuat manusia mengalami "amnesia" (lupa anak dan istri atau suami). Akibatnya hubungan antar anggota keluarga renggang, satu sama lain asyik dengan layarnya masingmasing. Hal ini baru dalam rumah tangga sendiri, apalagi dengan tetangga, mungkin 
bertemu tetangga hanya ketika bendera putih (tanda kematian) berdiri di depan rumah tetangga. Ketika itu, baru kita sadar ada anggota tetangga yang wafat. Dengan sedikit basa-basi kita membesuk sebentar sebelum pergi ke kantor (Bakhtiar, 2012, p.223).

Teknologi layar mampu membius manusia untuk tunduk pada layar dan mengabaikan yang lain. Jika manusia tidak sadar akan hal ini, maka dia akan kesepian dan kehilangan sesuatu yang amat penting dalam dirinya, yakni kebersamaan, hubungan kekeluargaan, dan sosial yang hangat. Jika pengaruh teknologi yang demikian semakin dalam, manusia tidak sadar akan kebutuhan yang sebenarnya. Ibarat orang yang pertama kali tinggal di dekat kandang ayam. Pada minggu pertama tidurnya susah kalaupun bisa hanya satu atau dua jam saja karena bau yang menyengat. Minggu kedua sudah agak biasa menyesuaikan diri dengan bau itu dan pada minggu-minggu selanjutnya sudah terbiasa. Setelah bertahun-tahun tinggal di sana sudah rindu pada bau tersebut, bahkan tidak bisa tidur kalau belum disertai "wewangian" kandang ayam.

Teknologi yang sedang melanda kehidupan kita sekarang juga ibarat orang yang betah tinggal di samping kandang ayam tadi, saking asyiknya dia tidak sadar bahwa teknologi layar membuat dia terpinggirkan dari sebuah kebutuhan mendasar. Dia hanya berimajinasi sesuai dengan apa yang ditayangkan televisi, apalagi yang menonton itu adalah anak-anak yang belum mampu membedakan antara yang nyata dan visual. Tuntutan melarang penayangan acara Smack Down di salah satu stasiun televisi adalah suatu contoh betapa besarnya akibat acara tersebut bagi kepribadian anak. Anak Sekolah Dasar dan Menengah yang meniru apa yang mereka tonton dan tidak segan-segan berbuat sadis sehingga berakibat fatal bagi fisik dan bahkan ada yang meninggal (Amsal Bakhtiar, 2012, pp.224-225).

Manusia saat ini benar-benar telah menjadi budak dari teknologi. Berdasarkan survei yang dilakukan Secur Envoy, sebuah perusahaan yang mengkhususkan diri dalam password digital, yang melakukan survei terhadap 1.000 orang di Inggris menyimpulkan bahwa mahasiswa masa kini mengalami nomophobia, yaitu perasaan cemas dan takut jika tidak bersama telepon selulernya. Hasil survei menunjukkan, 66 persen responden mengaku tidak bisa hidup tanpa telepon selulernya. Persentase ini semakin membengkak pada responden berusia 18 dan 24 tahun. Sebanyak 77 persen responden di antara kelompok usia ini mengalami nomophobia (http://kampus.okezone.com/read/2012/03/26).

Sementara itu riset yang lain dilakukan Zogby International di Amerika Serikat menunjukkan 24 persen dari 1.950 responden yang terdiri dari orang dewasa menyatakan internet memberikan dampak yang signifikan dalam hidup mereka. Menurut perusahaan riset tersebut, sebagian besar masyarakat mengatakan tak bisa hidup tanpa internet dan membutuhkan konektivitas dengan kecepatan tinggi. Sebanyak 22 persen dari peserta penelitian itu mengaku mengakses facebook ketika berinternet dan 10 persennya mengunjungi situs Google. Ketika ditanya prediksi mereka tentang teknologi informasi masa depan, 40 persen dari responden membayangkan dalam beberapa tahun ke depan akan ditanam sebuah cip di tubuh seluruh warga dunia. Cip ini berfungsi untuk memantau kondisi kesehatan dan mendeteksi keberadaan orang tersebut. Sebagian dari mereka juga meyakini berbagai pekerjaan yang dilakukan manusia akan beralih ke robot. Zogby menambahkan, kemajuan teknologi juga akan terasa di bidang kesehatan khususnya dalam pengembangan teknik kloning untuk menciptakan organ tubuh manusia dan sistem cell

(http://www.tempo.co/read/news/2010/12/23).

\section{PEMBAHASAN}

\section{Kemajuan Teknologi}

\section{Konsep Teknologi}

Manusia pada awalnya tidak mengenal konsep teknologi. Kehadiran manusia purba pada masa pra sejarah, hanya mengenal teknologi sebagai alat bantunya dalam mencari makan, alat bantu dalam berburu, serta mengolah makanan. Alat bantu yang mereka gunakan sangatlah sederhana, terbuat dari bambu, kayu, batu, dan bahan sederhana lain yang mudah mereka jumpai di alam bebas. Misalnya untuk membuat perapian, ia memanfaatkan bebatuan yang dapat memunculkan percikan api. 
Pada awalnya teknologi berkembang secara lambat. Namun seiring dengan kemajuan tingkat kebudayaan dan peradaban manusia perkembangan teknologi berkembang dengan cepat. Semakin maju kebudayaannya, semakin berkembang teknologinya karena teknologi merupakan perkembangan dari kebudayaan yang maju dengan pesat (Adib, 2011, p.254).

Secara harfiah teknologi berasal dari bahasa Yunani, yaitu "tecnologia" yang berarti pembahasan sistematik mengenai seluruh seni dan kerajinan. Istilah tersebut memiliki akar kata "techne" dalam bahasa Yunani kuno berarti seni (art), atau kerajinan (craft). Dari makna harfiah tersebut, teknologi dalam bahasa Yunani kuno dapat didefinisikan sebagai seni memproduksi alat-alat produksi dan menggunakannya. Definisi tersebut kemudian berkembang menjadi penggunaan ilmu pengetahuan sesuai dengan kebutuhan manusia. Teknologi dapat pula dimaknai sebagai "pengetahuan mengenai bagaimana membuat sesuatu (know-how of making things) atau "bagaimana melakukan sesuatu" (know-how of doing things), dalam arti kemampuan untuk mengerjakan sesuatu dengan nilai yang tinggi, baik nilai manfaat maupun nilai jualnya (Martono, 2012, p.276).

Dalam konsep yang pragmatis dengan kemungkinan berlaku secara akademis dapatlah dikatakan, bahwa ilmu pengetahuan (body of knowledge), dan teknologi sebagai suatu seni (state of art) yang mengandung pengertian berhubungan dengan proses produksi; menyangkut cara bagaimana berbagai sumber, tanah, modal, tenaga kerja, dan keterampilan dikombinasikan untuk merealisasikan tujuan produksi. "secara konvensional mencakup penguasaan dunia fisik dan biologis, tetapi secara luas juga meliputi teknologi sosial, terutama teknologi sosial pembangunan sehingga teknologi itu adalah metode sistematis untuk mencapai setiap tujuan Insani" (Dwiningrum, 2012, p.153).

Henslin menjelaskan bahwa istilah teknologi dapat mencakup dua hal. Pertama, teknologi menunjuk pada peralatan, yaitu unsur yang digunakan untuk menyelesaikan tugas. Teknologi merujuk pada peralatan sedemikian sederhana-seperti sisir-sampai yang sangat rumit-seperti komputer. Kedua, keterampilan atau prosedur yang diperlukan untuk membuat dan menggunakan peralatan tersebut. Teknologi dalam kasus ini tidak hanya merujuk pada prosedur yang diperlukan untuk membuat sisir dan komputer, akan tetapi juga meliputi prosedur untuk memproduksi suatu tatanan rambut yang dapat diterima, atau untuk dapat memasuki jaringan internet.

Secara sosiologis, teknologi memiliki makna yang lebih mendalam daripada peralatan. Teknologi menetapkan suatu kerangka bagi kebudayaan non material suatu kelompok. Jika teknologi suatu kelompok mengalami perubahan, maka cara berpikir manusia juga akan mengalami perubahan. Hal ini juga berdampak pada cara mereka berhubungan dengan yang lain. Bagi Marx, teknologi merupakan alat, dalam pandangan materialisme historis hanya menunjuk pada sejumlah alat yang dapat dipakai manusia untuk mencapai kesejahteraan. Weber mendefinisikan teknologi sebagai ide atau pikiran manusia itu sendiri. Sementara itu menurut Durkheim, teknologi merupakan kesadaran kolektif yang bahkan diprediksi dapat menggantikan kedudukan agama dalam masyarakat (Martono, 2012, pp.277-278).

Perkembangan teknologi akan mengalami beberapa siklus. Jacob menjelaskan beberapa siklus perkembangan ilmu pengetahuan dan teknologi menjadi lima tahapan. Lima tahapan tersebut dinyatakan sebagai lima siklus kondratif, yaitu suatu siklus yang akan berulang setiap 50 tahun. Kelima siklus tersebut adalah: pertama, dimulai dengan revolusi teknologi (tahun 1760); kedua, ditandai dengan terbentangnya jaringan kereta api (tahun 1848); ketiga, dimulai dengan ditemukannya ban berjalan (tahun 1895); keempat, ditandai dengan ditemukannya tenaga atom dan motorisasi massal (tahun 1945); dan kelima, ditandai dengan perkembangan mikro elektronik serta bioteknologi.

Teknologi memperlihatkan fenomenanya dalam masyarakat sebagai hal impersonal dan memiliki otonomi mengubah setiap bidang kehidupan manusia menjadi lingkup teknis. Sastrapratedja (Dwiningrum, 2012, p.154) menjelaskan bahwa fenomena teknik pada masyarakat kini, memiliki ciri-ciri sebagai berikut:

a. Rasionalitas, artinya tindakan spontan oleh teknik diubah menjadi tindakan yang direncanakan dengan perhitungan rasional. 
b. Artifisialitas, artinya selalu membuat sesuatu yang buatan tidak alamiah.

c. Otomatisme, artinya dalam hal metode, organisasi, dan rumusan dilaksanakan serba otomatis. Demikian pula dengan teknik mampu mengeliminasikan kegiatan non-teknis menjadi kegiatan teknis.

d. Teknik berkembang pada suatu kebudayaan

e. Monisme, artinya semua teknik bersatu, saling berinteraksi dan saling bergantung.

f. Universalisme, artinya teknik melampaui batas-batas kebudayaan dan ideologi, bahkan dapat menguasai kebudayaan.

g. Otonomi, artinya teknik berkembang menurut prinsip-prinsip sendiri.

Teknologi yang berkembang dengan pesat, meliputi berbagai bidang kehidupan manusia. Masa sekarang nampaknya sulit memisahkan kehidupan manusia dengan teknologi, bahkan sudah merupakan kebutuhan manusia. Awal perkembangan teknologi yang sebelumnya merupakan bagian dari ilmu atau bergantung dari ilmu, sekarang ilmu dapat pula bergantung dari teknologi. Contohnya dengan berkembang pesatnya teknologi komputer dan satelit ruang angkasa, maka diperoleh pengetahuan baru dari hasil kerja kedua produk teknologi tersebut (Dwiningrum, 2012, p.155).

Berdasarkan uraian pendapat di atas kita dapat menyimpulkan dan menarik suatu benang merah bahwa teknologi merupakan hasil olah pikir manusia yang pada akhirnya digunakan manusia untuk mewujudkan berbagai tujuan hidupnya, teknologi menjadi sebuah instrumen untuk mencapai tujuan. Teknologi juga merupakan hasil perkembangan rasionalitas manusia. Ketika keberadaan teknologi dikembangkan dalam struktur tindakan manusia, maka keberadaan teknologi juga dapat ditempatkan dalam kerangka perkembangan rasionalitas manusia tersebut.

Ketika manusia masih berada pada tahap irasional (bersifat tradisional dan afektif), manusia telah mampu menghasilkan berbagai teknologi yang masih sederhana. Seiring dengan perkembangan rasionalitasnya, manusia telah menghasilkan berbagai teknologi yang cukup rumit, namun pada akhirnya keberadaan teknologi tersebut dimanfaatkan sebagai alat untuk mencapai tujuan hidup manusia. Teknologi telah mempengaruhi pola pikir manusia itu sendiri, dan akibatnya secara tidak langsung teknologi juga sangat mempengaruhi tindakan, dan pola hidup manusia. Teknologi juga dimaknai sebagai alat yang memperlebar perbedaan kelas dalam masyarakat. Teknologi menjadi simbol status bagi si kaya dan si miskin, siapa yang mampu menguasai teknologi, maka ia akan mampu menguasai manusia yang lain.

Manusia menggunakan konsep teknologi baru untuk menunjuk pada timbulnya suatu teknologi yang membawa dampak penting pada kehidupan sosial. Bagi orangorang yang hidup 500 tahun yang lalu, teknologi-baru menunjuk pada proses pencetakan, sedangkan pada masa sekarang, teknologi baru menunjuk pada komputer, satelit, pesawat atau teknologi komunikasi yang lain. Perubahan kehidupan manusia yang semula berbasis pertanian menjadi berbasis industri juga sangat dipengaruhi oleh perkembangan teknologi.

\section{Janji Teknologi}

Suatu hal yang perlu mendapat perhatian khusus adalah bahwa setiap perkembangan teknologi selalu menjanjikan kemudahan, efisiensi, serta peningkatan produktivitas. Memang pada awalnya teknologi diciptakan untuk mempermudah manusia untuk memenuhi segala kebutuhan hidupnya. Berikut ini ada beberapa hal yang dijanjikan teknologi (Martono, 2012, pp.289-291).

1) Teknologi menjanjikan perubahan

Setiap penemuan baru akan melahirkan berbagai perubahan dalam suatu masyarakat. Ibarat sebuah subsistem, kehadiran teknologi baru sebagai subsistem baru dalam masyarakat akan membawa konsekuensi, subsistem lain dalam sistem tersebut mau tidak mau harus menyesuaikan diri akibat kehadiran teknologi tersebut. Teknologi pasti akan mengubah pola aktifitas keseharian individu. Kehadiran televisi di rumah misalnya, akan menyebabkan munculnya agenda baru setiap hari, ada jadwal menonton acara favorit yang sebelumnya tidak ada. Jadwal mandi, jadwal makan, jadwal minum kopi, jadwal membersihkan rumah, jadwal belajar, jadwal kencan, sampai jadwal tidur akan disesuaikan dengan jadwal acara di televisi. Bahkan susunan perabotan di rumah, meja, kursi, lemari, 
karpet, sofa, akan disesuaikan dengan di mana kita meletakkan televisi.

2) Teknologi menjanjikan kemajuan

Teknologi merupakan simbol kemajuan. Siapa saja yang mampu mengakses teknologi, maka ia akan mengalami sedikit atau banyak kemajuan ke arah entah dalam bentuk apa pun. Seseorang tidak akan ketinggalan informasi mana kala ia menggenggam sebuah teknologi. Teknologi telah mempengaruhi gaya hidup, dan bahkan teknologi juga telah menjadi gaya hidup itu sendiri.

3) Teknologi menjanjikan kemudahan

Teknologi memang diciptakan untuk memberikan kemudahan bagi individu. Orang tidak perlu susah-susah untuk menghubungi sanak keluarganya di luar kota, bahkan di luar negeri; mereka cukup menekan beberapa nomor melalui hanphone. Orang tidak perlu mengantri di depan petugas teller bank untuk melakukan berbagai transaksi, kita cukup masuk ke ruang ATM dan kita dapat melakukan berbagai transaksi menggunakan mesin tersebut, mulai mengambil uang, membayar tagihan listrik, air, telepon, membeli pulsa, membeli tiket kereta api, pesawat, kapal, membayar SPP, mengirim uang ke rekening lain, sampai membayar tagihan kredit. Ketika kita lapar, kita cukup menekan beberapa nomor delivery order, kemudian dalam beberapa menit, petugas pengantar makanan sampai di depan pintu rumah kita. Kita dapat memanfaatkan pesawat terbang untuk melakukan perjalanan jauh dalam waktu singkat; kita tidak perlu bersusah payah naik ke lantai yang lebih tinggi di sebuah gedung bertingkat, kita cukup memanfaatkan lift atau eskalator.

4) Teknologi menjanjikan peningkatan produktifitas

Perusahaan besar banyak memanfaatkan teknologi untuk alasan efisiensi dan peningkatan produktivitas daripada harus mempekerjakan tenaga kerja manusia yang memakan banyak anggaran untuk menggaji mereka. Teknologi juga dapat meningkatkan keuntungan perusahaan dengan berlipat ganda. Teknologi juga dapat dimanfaatkan sebagai alat kontrol untuk mengevaluasi kinerja seseorang. Teknologi finger print (sistem presensi dengan memanfaatkan sidik jari) misalnya, akan dapat mengontrol tingkat kehadiran karyawan di kantor.
5) Teknologi menjanjikan kecepatan

Berbagai pekerjaan akan dapat diselesaikan dengan cepat manakala kita memanfaatkan teknologi. Keberadaan komputer akan membantu mempercepat pekerjaan di kantor, mempercepat pembukuan, teknologi juga akan mempercepat proses pengiriman dokumen, surat atau file, serta barang. Memasak nasi akan lebih cepat jika menggunakan rice cooker. Semua pekerjaan dan setiap kesulitan akan teratasi dengan teknologi.

6) Teknologi menjanjikan popularitas

Manusia dengan mudahnya muncul di layar kaca melalui internet. Situs You Tube akan memfasilitasi kita untuk bergaya, bisa menjadi narsis, menampakkan dan mempromosikan wajah dan penampilan kita di internet, hanya dengan berbekal kamera dan modem untuk dapat meng-upload rekaman gambar yang kita miliki. kita dapat bergaya sesuka hati, dan masyarakat di seluruh dunia dapat dengan mudah menonton aksi kita. Banyak artis dadakan yang sangat terkenal setelah ia meng-upload video mereka melalui You Tube, misalnya: Sinta dan Jojo, dan Briptu Norman Kamaru. Semaunya dapat anda lakukan dengan bantuan teknologi. Tidak hanya itu, kita dapat mencari teman bahkan bertemu jodoh anda melalui teknologi. Sungguh suatu hal yang sulit dilakukan di masa lampau, kini ada dalam kenyataan di depan kita. Namun, ada juga aksi-aksi nakal para anak muda yang menyalahgunakan internet. Lihat saja jutaan video porno yang dapat dengan mudah di-upload dan di-download melalui internet. Hal ini semakin menguatkan pendapat bahwa kita dapat berbuat apa saja dengan teknologi. Kita dapat memperoleh keuntungan, sekaligus kita juga dapat memperoleh banyak kerugian.

\section{Masyarakat Digital}

Era modern diidentikkan dengan era masyarakat digital. Setiap aktivitas manusia akan digerakkan melalui serangkaian teknologi digital. Teknologi ini dioperasikan dengan menekan beberapa digit (angka) yang di susun dengan berbagai urutan. Relasi yang terbangun di antara individu adalah relasi pertukaran digital, setiap manusia hanya melakukan serangkaian transaksi atau interaksi melalui simbol-simbol digital. Transaksi perdagangan, komunikasi, semuanya digerakkan 
secara digital. Setiap individu akan memiliki identitas digital yang mampu mengenali siapa dirinya, setiap manusia sudah diberi nomor urut: melalui nomor identitas (e-KTP), nomor handphone, nomor telepon, nomor rekening bank, nomor ATM, nomor rekening listrik, rekening telepon, rekening air, PIN (Personal Identification Number) ATM, semuanya menggunakan sistem digital.

Interaksi antarmanusia digerakkan dengan teknologi serba digital: komputer, internet, mesin ATM, telepon, handphone, dan sebagainya, semuanya digerakkan secara digital. Kita dapat membeli sesuatu hanya dengan menggesek kartu ATM dan menekan beberapa nomor PIN, demikian halnya untuk membayar tagihan kamar hotel, membeli tiket, dan sebagainya. Pengiriman uang dapat dilakukan dalam hitungan detik hanya dengan menekan beberapa digit nilai uang yang akan dikirim dan beberapa digit nomor rekening tujuan. Bukan uang yang dikirim, melainkan hanya sederet angka yang berpindah dari rekening satu ke rekening yang lain (Martono, 2012, p.292).

\section{Teori Perubahan Sosial Budaya}

Para sosiolog dan antropolog mempunyai pendapat yang berbeda mengenai perubahan sosial diantaranya (Soekanto, 1990, pp.332-337):

1) Gillin dan Gillin, mengartikan perubahan sosial adalah suatu variasi dari cara hidup yang telah diterima, baik karena perubahan-perubahan kondisi geografis, kebudayaan material, komposisi penduduk, dan ideologi maupun karena adanya difusi ataupun penemuan-penemuan baru dalam masyarakat

2) Larson dan Rogers, mengemukakan pengertian tentang perubahan sosial yang dikaitan dengan adopsi teknologi yaitu perubahan sosial merupakan suatu proses yang berkesinambungan dalam suatu bentangan waktu tertentu. Pemakaian teknologi tertentu oleh suatu warga masyarakat akan membawa suatu perubahan sosial yang dapat diobservasi lewat perilaku anggota masyarakat yang bersangkutan.

3) Soerjono Soekanto, mendefinisikan perubahan sosial adalah segala perubahan yang terjadi dalam lembaga kemasyara- katan dalam suatu masyarakat, yang mempengaruhi sistem sosialnya.

Gejala-gejala yang dapat mengakibatkan perubahan sosial memiliki ciri-ciri antara lain (Martono, 2012, p.13):

1) Setiap masyarakat tidak akan berhenti berkembang karena mereka mengalami perubahan baik lambat maupun cepat.

2) Perubahan yang terjadi pada lembaga kemasyarakatan tertentu akan diikuti dengan perubahan pada lembaga-lembaga sosial lainnya.

3) Perubahan sosial yang cepat dapat mengakibatkan terjadinya disorganisasi yang bersifat sementara sebagai proses penyesuaian diri.

4) Perubahan tidak dibatasi oleh bidang kebendaan atau bidang spiritual karena keduanya memiliki hubungan timbal balik yang kuat.

Dari definisi perubahan di atas dapat disimpulkan bahwa perubahan sosial budaya merupakan suatu perubahan yang menyangkut banyak aspek dalam kehidupan seperti kesenian, ilmu pengetahuan, teknologi, aturanaturan hidup berorganisasi, dan filsafat. Jadi, teknologi merupakan salah satu faktor yang berpengaruh terhadap terjadinya perubahan sosial budaya.

Perubahan sosial mempunyai tiga dimensi, yaitu: struktural, kultural, dan interaksional. Pertama, dimensi struktural mengacu pada perubahan-perubahan dalam bentuk struktur masyarakat, menyangkut perubahan dalam peranan, munculnya peranan baru, perubahan dalam struktur kelas sosial, dan perubahan dalam lembaga sosial. Kedua, dimensi kultural mengacu pada perubahan kebudayaan dalam masyarakat. Perubahan ini meliputi; (1) inovasi kebudayaan, merupakan komponen internal dalam suatu masyarakat. Inovasi kebudayaan yang paling mudah ditemukan adalah munculnya teknologi baru. Kebutuhan masyarakat yang semakin kompleks memaksa individu untuk berpikir kreatif dalam upaya untuk memenuhi kebutuhan tersebut. (2) difusi, merupakan komponen eksternal yang mampu menggerakkan terjadinya perubahan sosial. Sebuah kebudayaan mendapatkan pengaruh dari budaya lain, kemudian memicu perubahan kebudayaan dalam masyarakat yang "menerima" unsur-unsur budaya tersebut. (3) integrasi, merupakan 
wujud perubahan budaya yang "relatif lebih halus". Hal ini disebabkan dalam proses ini terjadi penyatuan unsur-unsur kebudayaan yang saling bertemu untuk kemudian memunculkan kebudayaan baru sebagai hasil penyatuan berbagai unsur-unsur budaya tersebut (Martono, 2012, p.6).

Ketiga, dimensi interaksional mengacu pada adanya perubahan hubungan sosial dalam masyarakat. Dimensi ini meliputi (Martono, 2012, pp.7-8):

a. Perubahan dalam frekuensi. Perkembangan teknologi telah menyebabkan berkurangnya frekuensi individu untuk saling bertatap muka. Semua kebutuhan untuk berinteraksi dapat dipenuhi dengan memanfaatkan teknologi. Seorang nasabah bank tidak perlu berulang kali bertemu dengan petugas teller bank. Fungsi dan peran teller bank telah tergantikan oleh mesin ATM (Automatic Teller Machine atau Anjungan Tunai Mandiri) yang mampu melayani nasabah selama 24 jam di mana saja, tanpa harus mengantri lama, atau menulis formulir tertentu.

b. Perubahan dalam jarak sosial. Perkembangan teknologi informasi dan komunikasi telah menggeser fungsi "tatap muka" dalam proses interaksi. Individu tidak harus bertatap muka untuk dapat melakukan komunikasi dan interaksi secara langsung. Bahkan ketika dua individu berada di tempat yang sangat jauh, mereka bisa tetap berkomunikasi meskipun dalam jarak ribuan kilometer.

c. Perubahan perantara. Mekanisme kerja individu dalam masyarakat modern banyak bersifat serba "online", menyebabkan individu tidak banyak membutuhkan "orang lain" dalam proses pengiriman informasi. Pada zaman dulu, seorang raja yang ingin menyampaikan berita untuk kerajaan tetangga, menyuruh prajurit untuk menyampaikan surat ke kerajaan tetangga tersebut. Namun, pada masa modern sekarang, informasi antar negara dapat langsung disampaikan tanpa melalui orang lain sebagai perantara.

d. Perubahan dari aturan atau pola-pola. Banyak aturan serta pola-pola hubungan yang mengalami perubahan seiring perkembangan masyarakat. Emansipasi perempuan dalam dunia kerja misalnya, telah mengubah cara pandang masyarakat dalam menyikapi "perempuan yang pulang malam". Bila sebelumnya perempuan yang sering keluar atau pulang malam sering dikonotasikan sebagai "perempuan nakal", namun sekarang masyarakat telah memandang hal tersebut sebagai hal yang biasa karena pada saat sekarang banyak perempuan yang bekerja sampai larut malam atau bahkan bekerja pada malam hari.

5) Perubahan dalam bentuk interaksi. Interaksi antar individu tidak sekaku pada masa lalu ketika interaksi harus dilakukan secara tatap muka. Di era sekarang, interaksi dapat dilakukan kapan saja melalui telepon, handphone, email, chatting, facebook, Yahoo!Messenger, Twitter, Internet Relay Chatting, dan berbagai teknologi canggih lainnya.

Perubahan sosial terbagi atas dua wujud sebagai berikut: 1). Perubahan dalam arti kemajuan (progress) atau menguntungkan. 2) Perubahan dalam arti kemunduran (regress) yaitu yang membawa pengaruh kurang menguntungkan bagi masyarakat. Jika perubahan sosial dapat bergerak ke arah suatu kemajuan, masyarakat akan berkembang. Sebaliknya, perubahan sosial juga dapat menyebabkan kehidupan masyarakat mengalami kemunduran. Kemajuan teknologi di satu sisi merupakan contoh perubahan sosial yang bersifat kemajuan karena mempermudah aktivitas manusia dalam memenuhi kebutuhan hidupnya. Namun, di sisi lain kemajuan teknologi juga merupakan contoh perubahan sosial yang bersifat kemunduran karena manusia menjadi tergantung dengan teknologi (budak teknologi) bukan manusia yang menguasai teknologi akan tetapi teknologi yang menguasai manusia.

\section{Perubahan Pola Hidup Akibat Kemajuan Teknologi}

Dahulu, para petani di lingkungan tempat tinggal saya masih menggunakan bantuan tenaga hewan dalam mengerjakan/membajak sawahnya dan juga dibantu oleh tetangga dalam menanam padi atau tanaman lainnya. Namun saat ini, dengan berkembangnya teknologi, para petani telah menggunakan traktor dalam membajak sawah dan juga sudah menggunakan mesin perontok padi untuk mengolah hasil panenannya. Selain teknologi 
dalam bidang pertanian, teknologi yang berkaitan dengan komunikasi pun berkembang pesat. Dahulu, apabila ingin berkomunikasi jarak jauh memerlukan waktu yang lama. Akan tetapi, alat komunikasi saat ini sudah canggih. Misalnya melalui telepon seluler yang saat ini satu orang tidak hanya memiliki satu alat komunikasi tersebut. Bahkan, sekarang anak usia remaja bahkan yang masih anak-anak sekalipun telah mengenal apa itu facebook, email, twitter, dan lain sebagainya. Itulah contoh-contoh perubahan pola hidup manusia akibat kemajuan teknologi.

Pola hidup manusia selalu mengalami perubahan seiring perkembangan zaman. Kehidupan yang semakin modern membawa manusia pada pola perilaku yang unik, yang membedakan individu satu dengan individu lain dalam persoalan gaya hidup. Bagi sebagian orang gaya hidup merupakan suatu hal yang penting karena dianggap sebagai sebuah bentuk ekspresi diri. Pola hidup merupakan pola-pola tindakan yang membedakan antara satu orang dengan orang lain, yang berfungsi dalam interaksi dengan caracara yang mungkin tidak dapat dipahami oleh orang yang tidak hidup dalam masyarakat modern.

Menurut Talcott Parson (Dwiningrum, 2012, p.51), masyarakat modern digambarkan dengan ciri-ciri sebagai berikut:

a. Netralitas efektif yaitu bersikap netral, bahkan dapat menuju sikap tidak memperhatikan orang lain atau lingkungan.

b. Orientasi diri, yaitu lebih mengutamakan kepentingan diri sendiri.

c. Universalisme, yaitu menerima segala sesuatu dengan obyektif

d. Prestasi, yaitu masyarakatnya suka mengejar prestasi.

e. Spesifitas, yaitu berterus terang dalam mengungkapkan segala sesuatu.

Peran teknologi dalam mempengaruhi perubahan pola hidup manusia bukanlah sebuah hal yang perlu dipertanyakan lagi. Manusia tidak akan mampu hidup tanpa teknologi. Manusia purba, misalnya, telah lama mengenal teknologi sebagai alat bantu untuk memenuhi kebutuhan hidupnya, kebanyakan teknologi itu terbuat dari bahanbahan atau materi yang sangat sederhana. Teknologi dapat menyatukan masyarakat, dapat pula memisahkan masyarakat. Ada empat perubahan kecenderungan berpikir yang diakibatkan oleh perkembangan teknologi, yaitu: pertama, tumbuhnya reifikasi, yaitu anggapan bahwa yang semakin luas dalam kenyataan harus diwujudkan dalam bentukbentuk lahiriah dan diukur secara kuantitatif. Kedua, manipulasi yaitu kemampuan manipulasi yang tinggi bagi kerangka berpikir manusia yang disebabkan kemampuan teknologi dalam mengubah dan mengolah bendabenda alamiah menjadi sesuatu yang bersifat artifisial demi memenuhi kepentingan manusia. Ketiga, fragmentasi, yaitu adanya spesialisasi dalam pembagian kerja yang akhirnya menuntut profesionalisme dalam dunia kerja. Keempat, individualisasi, yang dicirikan dengan semakin renggangnya ikatan seseorang dengan masyarakatnya dan semakin besarnya peranan individu dalam tingkah laku sehari-hari (Martono, 2012, p. 278).

Pada masyarakat teknologi, ada tendensi bahwa kemajuan adalah suatu proses dehumanisasi secara perlahan-lahan sampai akhirnya manusia takluk pada teknik. Teknikteknik manusiawi yang dirasakan pada masyarakat teknologi, terlihat dari kondisi kehidupan manusia itu sendiri. Manusia pada saat ini telah begitu jauh dipengaruhi oleh teknik. Gambaran kondisi tersebut adalah sebagai berikut:

a. Situasi tertekan. Manusia mengalami ketegangan akibat penyerapan mekanisme-mekanisme teknik. Manusia melebur dengan mekanisme teknik, sehingga waktu manusia dan pekerjaannya mengalami pergeseran. Peleburan manusia dengan mekanisme teknik, menuntut kualitas dari manusia, tetapi manusia sendiri tidak hadir di dalamnya. Contohnya: pada sistem industri ban, seorang buruh meskipun sakit atau lelah, ataupun ada berita duka bahwa anaknya sedang sekarat di Rumah Sakit, mungkin pekerjaan itu tidak dapat ditinggalkan sebab akan membuat macet garis produksi dan upah bagi temannya. Keadaan tertekan demikian, akan menghilangkan nilai-nilai sosial dan tidak manusiawi lagi.

b. Perubahan ruang dan lingkungan manusia. Teknik telah mengubah lingkungan manusia dan hakikat manusia. Contoh yang sederhana manusia dalam hal makan atau tidur tidak ditentukan oleh lapar atau mengantuk tetapi diatur oleh jam. Ling- 
kungan manusia menjadi terbatas, manusia sekarang hanya berhubungan dengan bangunan tinggi yang padat, sehingga sinar matahari pagi tidak sempat lagi menyentuh permukaan kulit tubuh manusia.

c. Perubahan waktu dan gerak manusia. Akibat teknik, manusia terlepas dari hakikat kehidupan. Sebelumnya waktu diatur dan diukur sesuai dengan kebutuhan dan peristiwa-peristiwa dalam hidup manusia, sifatnya alamiah dan konkrit. Tetapi sekarang waktu menjadi abstrak dengan pembagian jam, menit dan detik. Waktu hanya mempunyai kuantitas belaka tidak ada nilai kualitas manusiawi atau sosial, sehingga irama kehidupan harus tunduk kepada waktu.

d. Terbentuknya suatu masyarakat massa. Akibat teknik, manusia hanya membentuk masyarakat massa, artinya ada kesenjangan sebagai masyarakat kolektif. Sekarang struktur masyarakat hanya ditentukan oleh hukum ekonomi, politik, dan persaingan kelas. Proses ini telah menghilangkan nilai-nilai hubungan sosial suatu komunitas. Terjadinya neurosa obsesional atau gangguan syaraf menurut beberapa ahli merupakan akibat hilangnya nilai-nilai hubungan sosial. Kondisi sekarang ini manusia sering dipandang menjadi objek teknik dan harus selalu menyesuaikan diri dengan teknik yang ada (Bachtiar, 2012, p.225).

e. Ternyata dunia modern yang mengukir kisah sukses secara materi dan kaya ilmu pengetahuan serta teknologi, sepertinya tidak cukup memberi bekal hidup yang kokoh bagi manusia, sehingga banyak manusia modern tersesat dalam kemajuan dan kemodernannya. Manusia modern kehilangan aspek moral sebagai fungsi kontrol dan terpasung dalam sangkar teknologi. Berdasar teori perubahan sosial budaya kemajuan teknologi telah menyebabkan kemajuan sekaligus kemunduran dalam kehidupan sosial budaya.

\section{Pengaruh Kemajuan Teknologi Bidang Sosial Budaya}

Beberapa bentuk perubahan perilaku sosial budaya akibat teknologi antara lain sebagai berikut:
1) Perbedaan kepribadian pria dan wanita. Banyak pakar yang berpendapat bahwa kini semakin besar porsi wanita yang memegang posisi sebagai pemimpin, baik dalam dunia pemerintahan maupun dalam dunia bisnis. Bahkan perubahan perilaku ke arah perilaku yang sebelumnya merupakan pekerjaan pria semakin menonjol.

2) Meningkatnya rasa percaya diri. Kemajuan ekonomi di negara-negara Asia melahirkan fenomena yang menarik. Perkembangan dan kemajuan ekonomi telah meningkatkan rasa percaya diri dan ketahanan diri sebagai suatu bangsa akan semakin kokoh. Bangsa-bangsa Barat tidak lagi dapat melecehkan bangsabangsa Asia.

3) Tekanan, kompetisi yang tajam di berbagai aspek kehidupan sebagai konsekuensi globalisasi, akan melahirkan generasi yang disiplin, tekun dan pekerja keras.

\section{Pengaruh Negatif}

Meskipun teknologi memberikan banyak manfaat bagi manusia, namun di sisi lain kemajuan teknologi akan berpengaruh negatif pada aspek sosial budaya:

a. Kemerosotan moral di kalangan warga masyarakat, khususnya di kalangan remaja dan pelajar. Kemajuan kehidupan ekonomi yang terlalu menekankan pada upaya pemenuhan berbagai ke-inginan material, telah menyebabkan sebagian warga masyarakat menjadi kaya dalam materi tetapi miskin dalam rohani.

b. Kenakalan dan tindak menyimpang di kalangan remaja semakin meningkat semakin lemahnya kewibawaan tradisitradisi yang ada di masyarakat, seperti gotong royong dan tolong-menolong telah melemahkan kekuatan kekuatan sentripetal yang berperan pen-ting dalam menciptakan kesatuan sosial. Akibat lanjut bisa dilihat bersama, kenakalan dan tindak menyimpang di kalangan remaja dan pelajar semakin meningkat dalam berbagai bentuknya, seperti perkelahian, corat-coret, pelanggaran lalu lintas sampai tindak kejahatan

c. Pola interaksi antarmanusia yang berubah. Kehadiran komputer pada kebanyakan rumah tangga golongan me- 
nengah ke atas telah merubah pola interaksi keluarga. Komputer yang disambungkan dengan telepon telah membuka peluang bagi siapa saja untuk berhubungan dengan dunia luar. Program Internet Relay Chatting (IRC), internet, dan email telah membuat orang asyik dengan kehidupannya sendiri. Selain itu tersedianya berbagai warung internet (warnet) telah memberi peluang kepada banyak orang yang tidak memiliki komputer dan saluran internet sendiri untuk berkomunikasi dengan orang lain melalui internet. Kini semakin banyak orang yang menghabiskan waktunya sendirian dengan komputer. Melalui program Internet Relay Chatting (IRC) anak-anak bisa asyik mengobrol dengan teman dan orang asing kapan saja (Siti Irene, 2012: 174175).

\section{Solusi Mengatasi Dampak Negatif Kemajuan Teknologi}

Kemajuan teknologi merupakan bagian dari konsekuensi modernitas dan upaya eksistensi manusia di muka bumi. Oleh karena itu, dampak negatif yang timbul sebagai akibat dari kemajuan teknologi menjadi kewajiban bersama umat manusia untuk mengatasinya. Dengan adanya consciousness (kesadaran) bersama maka kita yakin bahwa generasi mendatang akan lebih smart dan bermartabat. Berikut ini diuraikan peran yang semestinya dilakukan oleh keluarga, sekolah (institusi pendidikan), masyarakat, dan negara untuk menekan serta mengatasi pengaruh negatif dari kemajuan teknologi pada masyarakat postmodern.

Adapun peran keluarga diantaranya sebagai berikut.

1) Sebagai agen sosialisasi yang pertama dan yang utama, keluarga seharusnya dapat menanamkan nilai dan norma yang positif kepada anak dengan membekali dan meletakkan pondasi keimanan yang kokoh kepada anak. Hal ini dimaksudkan agar anak tidak menjadi angkuh dan melupakan Tuhan dalam aktifitas kehidupan modern yang serba canggih.

2) Keluarga harus selektif dalam menentukan skala prioritas kebutuhan teknologi bagi keluarga. Hal ini dilakukan dalam upaya untuk mengurangi cara hidup manusia modern yang cenderung konsumtif terhadap produk teknologi. Selain itu, penentuan skala prioritas diperlukan agar teknologi yang dipergunakan benar-benar memberikan manfaat yang besar bagi keluarga. Misalnya, jika suatu keluarga sudah memiliki sebuah televisi mereka tidak perlu membeli televisi untuk setiap anggota keluarga yang diletakkan di kamar masing-masing, karena hal itu akan mengakibatkan pemborosan dan merupakan pola hidup yang tidak efektif dan efisien.

3) Orang tua harus update terhadap perkembangan teknologi sehingga mereka tidak gaptek. Setidaknya orang tua modern saat ini harus memiliki kemampuan dalam penggunaan smartphone, internet basic (email, browsing, blogging, and cathing), dan jika memungkinkan penggunaan sosial media online seperti: yahoo messenger, facebook, twitter, skype, dan internet relay chatting.

4) Perlunya bimbingan dan pengawasan dari orang tua kepada anak-anaknya dalam pemanfaatan teknologi, khususnya teknologi informasi dan komunikasi seperti televisi, handphone, komputer dan internet. Upaya ini dapat dilakukan dengan cara sebagai berikut:

a) Membatasi saluran (chanel) televisi yang masuk agar tayangan-tayangan yang membawa dampak negatif bagi anak terutama pornografi, dan kekerasan tidak dengan mudah diterima oleh anak-anak kita.

b) Mendampingi anak saat menonton televisi sehingga kita dapat mengarahkan anak bahwa tidak semua yang dilihat di layar kaca merupakan kejadian yang sesungguhnya.

c) Orang tua melakukan pengecekan handphone anak secara insidental untuk memastikan bahwa mereka memanfaatkan teknologi komunikasi secara benar dan bertanggungjawab.

d) Berusaha meletakkan komputer dan saluran internet di ruang publik rumah seperti di ruang keluarga bukan di dalam kamar anak. Hal ini dimaksudkan agar anak-anak lebih mudah diawasi oleh orang tua.

e) Mem-block situs-situs internet yang berbahaya bagi perkembangan anak. 
f) Orang tua ikut menjadi teman anak dalam social media online.

g) Membuat kesepakatan dengan anak tentang waktu bermain komputer dan internet. Hal ini diperlukan agar ketika mereka dewasa dapat disiplin dan mampu melakukan manajemen waktu dengan baik. Selain itu, kesepakatan tentang waktu dapat mencegah anak dari kecanduan terhadap komputer dan internet serta dapat menghemat pengeluaran.

5) Orang tua meluangkan waktu untuk berkumpul, bermain, dan bercengkrama dengan anggota keluarga. Dengan demikian akan terjalin interaksi yang baik sehingga harmonisasi hubungan dalam keluarga dapat terjaga.

6) Menumbuhkan kesadaran kepada anak tentang dampak negatif dari teknlogi bagi kehidupan mereka di masa depan. Upaya ini dapat dilakukan dengan memberikan kebebasan kepada anak dalam memanfaatkan teknologi namun harus bisa dipertanggungjawabkan.

Peran sekolah diantaranya adalah sebagai berikut.

1) Sebagai lembaga yang memegang peran efektif dalam menanggulangi dampak negatif kemajuan teknlologi, sekolah perlu menetapkan seperangkat aturan atau tata tertib sekolah yang jelas kepada peserta didik berkaitan dengan pemanfaatan dan penggunaan teknologi di sekolah. Misalnya sekolah melarang siswa SMP membawa handphone ke sekolah. Aturan ini selain untuk menghindari halhal yang tidak diinginkan (pencurian hp) juga bermaksud agar siswa lebih fokus dalam pembelajaran di sekolah.

2) Dalam pembelajaran, guru selalu memberikan sosialisasi dan penekanan tentang manfaat serta dampak buruk dari teknologi bagi anak. Dengan demikian diharapkan siswa menjadi lebih bijaksana dalam memanfaatkan teknologi.

3) Mempertimbangkan pemakaian teknologi informasi dalam pendidikan, khususnya untuk anak di bawah umur yang masih harus dalam pengawasan ketika sedang melakukan pembelajaran dengan teknologi informasi. Sekolah hendaknya mela- kukan nalisis untung ruginya pemakaian teknologi tersebut bagi peserta didik.

4) Tidak menjadikan teknologi informasi sebagai media atau sarana satu-satunya dalam pembelajaran, misalnya sekolah tidak hanya mendownload $e$-book, tetapi masih tetap membeli buku-buku cetak, tidak hanya berkunjung ke digital libra$r y$, namun juga masih berkunjung ke perpustakaan.

5) Guru hendaknya memberikan pengajaran-pengajaran etika dalam berteknologi informasi agar teknologi informasi dapat dipergunakan secara optimal tanpa menghilangkan etika.

6) Menggunakan software yang dirancang khusus untuk melindungi 'kesehatan' anak. Misalnya saja program nany chip atau parents lock yang dapat memproteksi anak dengan mengunci segala akses yang berbau seks dan kekerasan.

7) Guru harus mampu menjadi sosok teladan bagi peserta didik dalam berteknologi yang bertanggung jawab, proporsional, dan profesional. Misalnya guru tidak membawa hp dan mengangkat telepon ketika sedang mengajar, guru tidak bermain game online atau facebook dan twiter ketika siswa diminta mengerjakan tugas.

8) Sekolah menjadi pioner dalam pemanfaatan teknologi yang ramah lingkungan dalam upaya pembangunan yang berkelanjutan. Misalnya menggunakan genset yang memiliki kadar emisi rendah dan menggunakan peredam suara sehingga tidak menimbulkan kebisingan yang mengganggu aktifitas pembelajaran, dan memanfaatkan hardware komputer yang telah rusak sebagai alat peraga pembelajaran.

9) Sekolah memberikan kegiatan ekstrakurikuler komputer dan internet agar siswanya tidak ketinggalan kemajuan teknologi. Selain itu sekolah juga dapat melakukan kegiatan ekstrakurikuler keterampilan teknologi sehingga siswa tidak hanya mahir sebagai end user dari teknologi tapi diharapkan siswa mampu memiliki ide, gagasan yang kreatif dan inovatif dalam menemukan teknologi tepat guna dalam ruang lingkup yang sederhana. 
berikut.

Peran masyarakat diantaranya sebagai

1) Masyarakat dalam kapasitasnya sebagai konsumen teknologi hendaknya perlu memfilter teknologi yang masuk ke dalam masyarakat. Dalam era globalisasi tentu masyarakatnya tidak harus seperti suku badui dalam (Banten) yang anti teknologi modern, tetapi masyarakat kita juga harus sadar bahwa kita sebagai masyarakat timur harus mampu mencerna teknologi yang bermanfaat bagi kemajuan masyarakat kita.

2) Dalam kapasitasnya sebagai produsen produk teknologi masyarakat hendaknya tidak hanya mementingkan market oriented dan profit oriented, namun perlu memikirkan dampak dari produk teknologi tersebut bagi masyarakat kita secara khusus dan masyarakat dunia pada umumnya. Artinya teknologi yang dikembangkan hendaknya bertujuan untuk meningkatkan peradaban manusia bukan untuk menghancurkannya. Contohnya, teknologi nuklir dikembangkan untuk mengatasi kelangkaan bahan bakar listrik bukan untuk senjata pemusnah massal.

3) Upaya-upaya masyarakat yang bersifat praktis antara lain:

a) Membuat website/blog/group facebook untuk suatu komunitas tertentu (contoh: grup Yogyakarta community) sebagai media interaksi dan upaya menjalin silaturahmi untuk sesama warga.

b) Membuat aturan khusus mengenai ijin mendirikan warnet (warung internet), game online, dan play station agar tidak menimbulkan keresahan dan gejolak di masyarakat.

c) Menggelar acara "nonton bareng" pada even-even tertentu. Misalnya pertandingan sepak bola. Dengan demikian masyarakat dapat saling berinteraksi dan mempererat keakraban, tali persaudaraan, dan persatuan.

d) Mengadakan pertemuan rutin di tingkat RT maupun Desa/kelurahan sebagai sarana interaksi secara langsung dan sosialisasi kepada masyarakat khususnya dalam membuat suatu konsensus tentang ketertiban, keamanan, dan kenyamanan masya- rakat terkait dengan penggunaan teknologi. Misalnya, pengendara sepeda motor harus berjalan pelanpelan ketika memasuki perkampungan, dan mematikan mesin sepeda motor ketika memasuki gang di atas jam 22.00.

e) Memanfaatkan kemajuan teknologi seperti internet untuk memasarkan produk-produk unggulan (cluster) dan memperkenalkan budaya setempat sehingga akan dikenal oleh masyarakat luas bahkan dunia yang berimbas pada perbaikan tingkat ekonomi dan kesejahteraan masyarakat.

Adapun peran negara diantaranya adalah sebagai berikut.

1) Sebagai regulator dan fasilitator negara hendaknya membuat peraturan khusus untuk membatasi situs-situs di internet yang berpotensi merusak moralitas masyarakat Indonesia. Misalnya, pemerintah melalui menkominfo melakukan tindakan blocking terhadap situs-situs pornografi, melakukan kritik terhadap tulisan atau artikel yang bernuansa SARA seperti kritik terhadap pembuatan karikatur Nabi Muhammad, atau film Innocense of Muslim yang baru-baru ini dibuat oleh orang Amerika Serikat.

2) Membuat aturan dan sanksi yang tegas terhadap penyalahgunaan internet dan kejahatan internet. Misalnya, memberikan hukuman kepada pelaku dan penyebar pornografi, bekerjasama dengan interpol untuk mencegah dan menangani kasus-kasus kejahatan internet (cyber crime).

3) Pemerintah harus menjadi contoh yang baik bagi masyarakat dalam berteknologi yang bijaksana, hemat, dan ramah lingkungan. Contoh, pejabat negara tidak menghamburkan uang untuk pembelian kendaraan dinas yang mahal, tidak boros dalam menggunakan listrik, dan tidak menyalahgunakan kekuasaan dan jabatan untuk mendapatkan fasilitas khusus di bidang teknologi.

4) Membuat kebijakan yang tepat berkaitan dengan kemajuan teknologi transportasi. Misalnya, subsidi BBM (BBM Premium) hanya untuk kendaraan angkutan, dan 
roda dua, serta kendaraan dengan kriteria khusus, membatasi kepemilikian kendaraan baik roda dua maupun roda empat untuk mengurangi tinngkat polusi dan kemacetan, menetapkan standar kadar emisi gas buang kendaraan tanpa rekayasa, menetapkan batas maksimum beban angkutan kendaraan (tonase) tanpa pungutan liar dari petugas, menyediakan sarana transportasi masa yang lebih baik, dan menjalankan program konversi bahan bakar yang lebih efisien dan berkelanjutan.

5) Mengembangkan Lembaga Riset dan Teknologi (Ristek) sebagai upaya untuk menuju kemandirian dan kemajuan bangsa. Misalnya, memperkuat kembali industri pesawat terbang (IPTN), krakatau steel, Pindad, otomotif (mobil kiat Esem$\mathrm{ka}$ ), dan industri lain yang memungkinkan untuk dikembangkan.

6) Tidak melakukan penjualan terhadap aset-aset negara yang strategis seperti komunikasi, pertambangan, minyak bumi kepada bangsa asing yang pada akhirnya menimbulkan dependensi yang berlebihan terhadap bangsa asing.

7) Memperkuat teknologi pertanian untuk menuju swasembada pangan sehingga kita tidak diibaratkan seperti "tikus yang mati dalam lumbung padi”.

8) Meningkatkan promosi budaya dan pariwisata dengan memanfaatkan teknologi informasi untuk membantu peningkatan pendapatan negara non pajak.

9) Memperkuat sektor ekonomi kerakyatan dan koperasi untuk mencegah kapitalisme asing akibat kemajuan industri dan difusi teknologi.

10) Membuat kebijakan berkaitan dengan kurikulum pendidikan nasional yang berorientasi pada penanaman nilai-nilai karakter dan budaya bangsa, yang berspektif global. Upaya ini dimaksudkan untuk menyiapkan generasi penerus bangsa yang handal, dengan penguasaan teknologi tinggi, memiliki daya saing global namun tetap menunjukkan identitas dan kepribadian khas Indonesia.

11) Strategi pengembangan ilmu pengetahuan dan teknologi (IPTEK) yang tidak bebas nilai akan tetapi value based (berdasarkan nilai) terutama nilai-nilai agama serta nilai-nilai luhur budaya dan kepribadian bangsa. Hal ini dimaksudkan agar di abad teknologi ini kita tetap menjadi bangsa yang religius dan berkepribadian unggul, tidak menjadi negara sekuler yang mengagungkan teknologi serta meniadakan Tuhan dalam aktivitas hidupnya.

\section{SIMPULAN}

Secara sosiologis, teknologi merupakan salah satu aspek yang turut mempengaruhi setiap aktivitas, tindakan, serta perilaku manusia. Teknologi mampu mengubah pola hubungan dan pola interaksi antar manusia. Kehadiran teknologi merupakan sesuatu yang tidak dapat dipisahkan dari kehidupan manusia. Aktivitas manusia sedikit banyak akan dipengaruhi oleh kehadiran teknologi. Kemajuan teknologi dewasa ini ditandai dengan semakin canggihnya alat-alat di bidang informasi dan komunikasi, satelit, bioteknologi, pertanian, peralatan di bidang kesehatan, dan rekayasa genetika. Muculnya masyarakat digital dalam berbagai bidang kehidupan merupakan bukti dari kemajuan teknologi. Masyarakat dan negara-negara di dunia berlombalomba untuk dapat menguasai teknologi tinggi (high tech) sebagai simbol kemajuan, kekuasaan, kekayaan dan prestise. Dalam masyarakat Postmodern berlaku hukum "barang siapa yang menguasai teknologi maka ia akan menguasai dunia".

Dalam era globalisasi, kemajuan teknologi berlangsung sangat cepat sehingga kadangkala manusia tidak sempat untuk beradaptasi dengan kemajuan tersebut. Akibatnya terjadi anomi dalam masyarakat karena mereka tidak mempunyai pegangan hidup yang jelas. Masyarakat yang tidak mampu menguasai teknologi akan mengalami cultural lag dan akan terancam eksistensinya.

Kemajuan teknologi ibarat dua sisi mata uang, di mana di satu sisi kemajuan teknologi memberikan banyak manfaat positif bagi manusia untuk mempermudah manusia dalam memenuhi kebutuhan hidupnya. Namun demikian disisi yang lain kemajuan teknologi menimbulkan efek negatif yang kompleks melebihi manfaat dari teknologi itu sendiri terutama terkait pola hidup manusia dalam dimensi sosial budaya. Teknologi mengancam kematian melalui berbagai penyakit, kerusakan lingkungan, pemanasan glo- 
bal, menciptakan ketegangan, memberikan berbagai resiko, belenggu atas diri manusia melalui sistem kontrol yang tersembunyi, dan dehumanisasi. Satu hal yang perlu kita ingat, teknologi selalu berwajah ganda, di satu saat ia menjadi teman, di saat yang lain, ia juga bisa menjadi lawan.

Upaya-upaya yang dapat kita lakukan sebagai solusi untuk menanggulangi dampak negatif dari kemajuan teknologi adalah dengan menanamkan kesadaran kepada setiap individu tentang pentingnya memahami dampak negatif kemajuan teknologi. Dengan analisa SWOT secara sederhana kita dapat menjadikan tantangan dan dampak negatif dari teknologi menjadi peluang untuk memajukan suatu masyarakat dan negara. Untuk itulah diperlukan peran serta aktif dari keluarga, sekolah, masyarakat, dan negara dalam mencegah, mengurangi, dan menanggulangi dampak negatif dari kemajuan teknologi. Sebagai manusia modern sangat tidak bijaksana serta tidak mungkin jika kita mengatakan say no to technology, namun yang harus kita lakukan yaitu mempertimbangkan kebutuhan kita terhadap teknologi, mempertimbangkan baik-buruknya teknologi tersebut dan tetap menggunakan etika, serta tidak terlalu berlebihan agar kita tidak kecanduan dan menjadi budak teknologi. Kita harus menyadari bahwa teknologi bukan merupakan aspek kehidupan umat manusia yang tertinggi. Tidak juga merupakan puncak kebudayaan dan peradaban umat manusia di dalam evolusinya mencapai kesempurnaan hidup (perfection of existence). Namun teknologi merupakan suatu alat yang digunakan manusia untuk mempermudah dalam melakukan sesuatu dalam aktivitas kehidupannya.

\section{DAFTAR PUSTAKA}

Adib, Mohammad. (2011). Filsafat ilmu: onto-logi, epistemologi, aksiologi, dan logika ilmu pengetahuan. Yogyakarta: Pustaka Pelajar.

Bachtiar, Amsal. (2012). Filsafat ilmu edisi revisi. Jakarta: Raja Grafindo Persada.

Buhal. (2000). Visi Iptek memasuki milenium III. Jakarta: UI Press.

Dwiningrum, S. I. A. (2012). Ilmu sosial \& budaya dasar. Yogyakarta: UNY Press.

Martono, Nanang. (2012). Sosiologi perubahan sosial: perspektif klasik, modern, postmodern, dan postkolonial. Jakarta: PT. Raja Grafindo Persada.

Meinita, Hanna. (Diambil pada tanggal 1 Februari 2013). Mahasiswa tak bisa hidup tanpa smartphone. http://kampus. okezone.com/read/2012/03/26/373/599 857/mahasiswa-tak-bisa-hidup-tanpasmartphone.

Rini K. (Diambil pada tanggal 1 Februari 2013). Survei: tak bisa hidup tanpa internet. $\quad \mathrm{http}: / / \mathrm{www} \cdot \mathrm{tempo} . \mathrm{co} / \mathrm{read}$ /news/ 2010/12/23/072301058/SurveiTak-Bisa-Hidup-Tanpa-Internet.

Soerjono Soekanto. (1990). Sosiologi suatu pengantar: edisi baru keempat. Jakarta: Rajawali Pers.

Sukplang, Sukree. (Diambil pada tanggal 3 Februari 2013). 10 Negara terhebat di dunia.

http://top10newsworld.blogspot.com/20 12/11/10-negara-terhebat-didunia.html.

Zamroni. (2008). The socio-cultural aspects of technological diffusion a reader volume IV. Yogyakarta: Pascasarjana Universitas Negeri Yogyakarta. 